\title{
Anthropology of Tourism: From Morocco to Papua New Guinea
}

\author{
Michaela Konopíková - Martin Soukup \\ Institute of Ethnology, Faculty of Arts, Charles University in Prague, 11000 Prague 1, Celetná 20
}

Received $10^{\text {th }}$ of April 2014; accepted $20^{\text {th }}$ of June 2014

\section{ANTROPOLOGIE TURISMU: Z MAROKA DO PAPUY-NOVÉ GUINEJE}

ABSTRAKT Studie se zabývá teoreticko-empirickou analýzou a interpretací antropologie turismu se zvláštním zřetelem ke dvěma lokalitám. Na základě terénních výzkumů jsou při výkladu předmětu brána v úvahu empirická data, jež autoři získali v Maroku a na Papui-Nové Guineji. Studie si klade za cíl analýzu sociokulturních mechanismů, s jejichž pomocí se lokální komunity adaptují na turistickou poptávku.

KLÍČOVÁ SLOVA antropologie turismu; kultura; Maroko; Papua-Nová Guinea

\begin{abstract}
The article deals with a phenomenon of tourism from a perspective of socio-cultural anthropology. It aims to introduce some basic approaches and key figures of the field, who contributed to the wider recognition of anthropology of tourism. The subject of the study is a theoretic and empirical analysis of anthropology of tourism, which is interpreted on the basis of the data obtained in two localities; namely Morocco and Papua New Guinea. The researchers gathered information, which allows them for an interpretation of the coping mechanisms engaged by the local populations.
\end{abstract}

KEY WORDS Anthropology of Tourism; Culture; Morocco; Papua New Guinea

\section{INTRODUCTION}

The study draws from anthropology of tourism, which represents a dynamic and expanding trend in contemporary social and cultural anthropology. The authors follow two main objectives: 1) outline the main concepts and theoretical approaches of anthropology of tourism; 2) describe and analyze tourism industry in two different localities where they conducted their field research - the High Atlas Mountains in Morocco and Saruwaged Range in North East Papua New Guinea. The distance between these two places is about 16000 kilometers, yet they have something in common a tourism boom which affects the local populations. The community members are getting involved in tourism industry in order to improve their income.

The aim of this article is to provide an outline of the key concepts and approaches frequented in contemporary socio-cultural anthropology. This is the central issue of the first part. The second part looks at the particular societies -
The Berber population in the mountains of Morocco, which has increasingly become a popular destination for mountain tourism and community in Papua New Guinea. The fieldwork conducted in the localities by the authors throws some light to the processes present in the tourism industry, and investigates their impact on the societies of the Global South. These findings may be applicable to the practices emerging from contact between tourists and locals in similar settings.

Some 100000 years ago Homo sapiens began the migration from Africa and populated the Middle East, to later successfuly colonize the rest of the planet. Our distant predecessors would migrate or travel together in order to obtain food for survival, or to escape harsh climate conditions. Later, however, the first nomadic people began to truly explore the Earth. It should be noted that our genetic code does not dramatically differ from that of our ancestors. Thus we still possess the powerful genetic trait, which drives us as well as our ancestors to explore new places. The Romans and early 
discoverers used to wander the country for the lust of life; merchants and subsequently colonists travelled with the objective to find and conquer land. This universal phenomenon is inscribed deep down in the physical body and soul of human beings. That is why people from time to time respond to the inner voice calling for adventures and unveiling unknown territories. The latest articulation of this voice has created a new phenomenon, which helped to transform the global reality quite considerably, and created an archetype of a modern nomad travelling without any particular reason. Tourism has become an industry spreading across the continents, modifying cultures and societies, and reaching out to the most isolated corners. As a social phenomenon, it has slowly come to the centre of attention of scientists, who are increasingly aware of its contribution to changing social and cultural situations.

\section{TOURISM AS A SUBJECT OF ANTHROPOLOGICAL RESEARCH}

British painter John Ruskin wondered whether it is possible to preserve the beauty of a place in ones mind. He concluded that the way to accomplish this suggested task is to depict the beautiful places with or via art. Further, he believed that it is not important as to what means are engaged i.e. painting, writing, drawing or some other talent of the individual. Ruskin once explained that his desire to draw derives from an instinct, similar to an instinct to eat and drink. "What unites the three activities is that they all involve assimilations by the self of desirable elements from the world, a transfer of goodness from without to within" (Botton 2010, 196).

Travelling and discovering new places bear the same characteristics. By visiting and seeing more or less exotic places, we usually do our best to keep a record of them. This record can be a vivid image or memory of a lovely view of an exotic valley where we spent an unforgettable weekend, or a memory of a local shopkeeper exercising her mastery in wrapping up fresh bakery. Another way of recording is using a camera to take a photograph of a picturesque medieval church in a lost village somewhere in the middle of nowhere, or preserve the moment when the local herdsman suddenly turned and gave us a big warm smile. Nowadays, the need for catching moments is treated as a subject of study, and provides many narratives to be examined: such as the topic of recording people who are themselves recording the locals. These people are more commonly referred to as Tourists.

Tourism consists of a few key elements: the coming people tourists, receiving population - locals, and finally the spot where the encounters take place. It should be noted that each element of tourism ought to be examined separately as well as the interactions among those elements.

At this moment, we can mention numerous motivations why people travel. These are a subject of scientific theories, which stem from different standpoints. Tourism is a cul- tural practice sui generis and definitely has a potential to change.

Another important element of tourists - locals interaction is the field, where such encounters take place. Adopting the theatrical perspective (the stage determines the nature of these interactions), these encounters create a new culture which is constructed specifically for a tourist audience (Brunner 2005, 5). As Edward Brunner further points out in his book Culture on Tour. Ethnographies of Travel (2005), the tourist performances are not only metaphors and representations, but above all, social practice, and it should be treated with respect to its nature. As the tourist activity is more a process than a static cultural fact, the analysis should reflect the act of tourism, its impact and also meaning to the tourist and the host population. International tourism is an exchange of vast proportions, characterized by a transfer of images, signs, symbols, power, money, goods, people, and services (Lanfant 1989, Smith 1977/1989).

The whole phenomenon started to be considered by anthropologists when they realized its inevitabe impact on studied communities. With growing mobility and accesibility to distant territories, the necessity to conceptualize a brand new social phenomenon arose. Consequently, new theories emerged to treat tourism and provide methodological ground to explanation. Below, we will introduce four main approaches, which derive from established concepts of social sciences. Each concept contributed to the constitution of a specific attitude to the discussed social fact.

\section{Tourism as a ritual of transition}

Some scholars noticed that (post)modern travelling shares common features with medieval pilgrimage and rituals. According to Victor Turner, who did a research on rites of passage, the act of opting out the rutine social structures and conventions constitutes a central feature of both pilgrimage and rites of passage. "During the intervening 'liminal' period, the characteristics of the ritual subject (the 'passenger') are ambiguous; he passes through a cultural realm that has few or none of the attributes of the past or coming state" (Turner 1977, 94). A person travelling to an unknown territory experiences exactly the same state because nobody knows him or her, and also he or she is not familiar with the place where he or she sets off. Travelling therefore provides an opportunity to saturate the need of escaping the everyday routine. For those who travel, holidays may mean a way to maintain cultural continuity. Being exposed to a different set of values, sometimes even contradictory to own, many times leads to a better understanding of oneself.

In the area of the High Atlas Mountains incoming people very often have to deal with a necessity to adapt their social status to be in compliance with the local cultural codes. We met a Dutch student couple, who had been travelling in Morocco for roughly two to three weeks. They admitted that they are regarded with a slight degree of suspicion and unbelief every time they reveal they are travelling together and are not ma- 


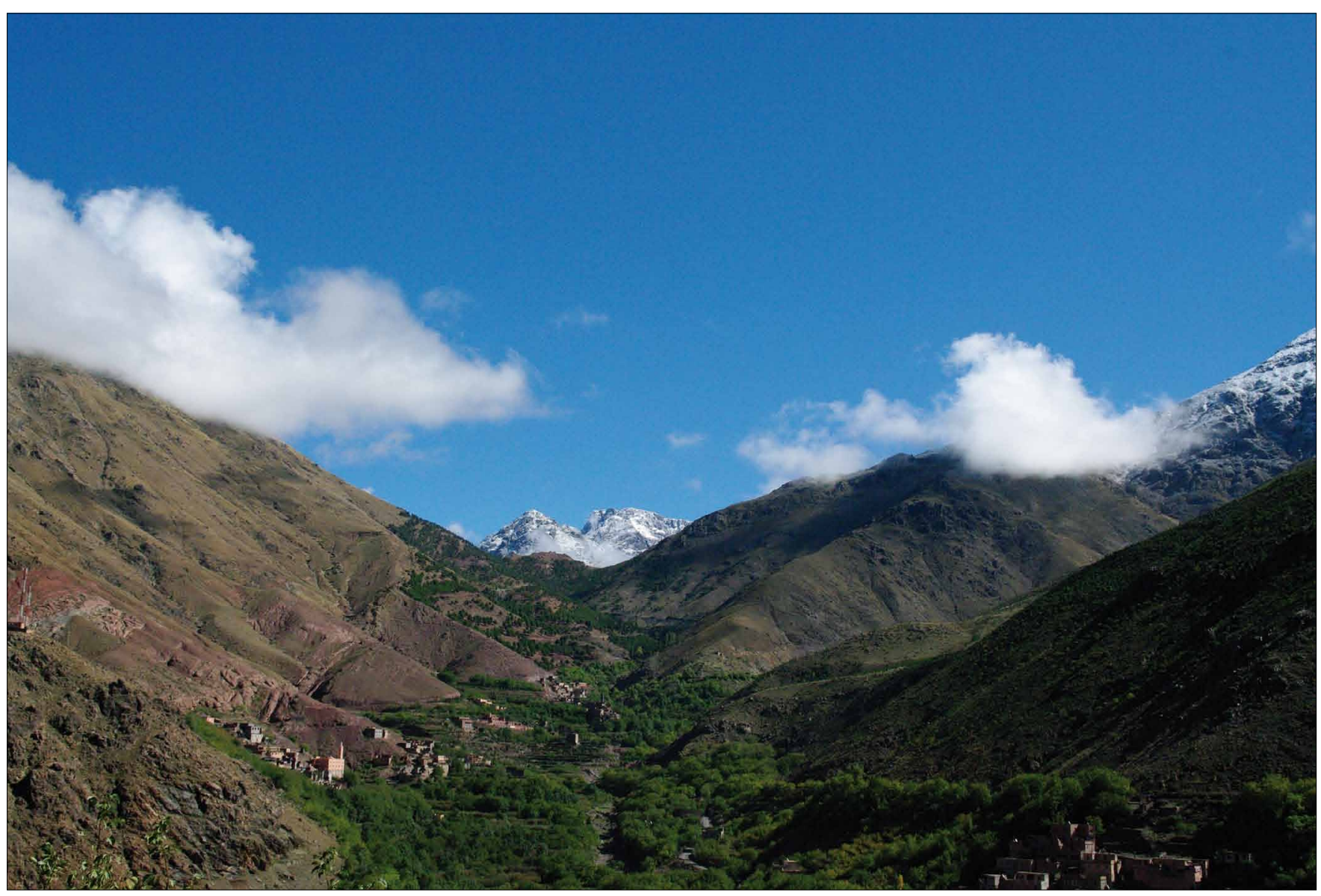

Fig. 1. Imlil Valley in the High Atlas Mountains.

rried. In a conservative Muslim society, such idea is inconceivable, and these two were expressing their amazement over the repeated disapproving reaction toward their confession. The debate, which arose hence brought us to discussions over the concepts of marriage, cohabitation and European liberalism, and this situation provided them an opportunity to think about who we are and how our social and cultural norms work in the context of the home society.

On the other hand, tourism to indigenous localities can „provide access to socially and culturally constructed "utopic" world, where people experience legitimate simplicity of communitas"(Wang 2010,65). Travelling to distant places can be regarded as a rite of passage where the participants get exempted from order, rigid and conformed situations. They spend a few days in places where their cultural norms might not be valid.

\section{Tourism as a form of superstructure}

The second theory derives from Marx materialistic theory and also from cultural materialism by Marvin Harris. It regards free time as a product of social superstructure, and due to the direct links between free time and tourism (the first is a necessary condition for the existence of the second) it places the whole phenomenon within the existing context. Though it is a phenomenon dependent on the materialist base of society, it bears a potential to influence other social activities, when for example the travel industry exerts political pressure in favour of its own interests (Nash 1996, 65). For existence of tourism, free time is an inevitable and necessary modality. It is usually defined as a sphere of human life detached from accomplishment of the routine daily tasks. It is a transcultural reality, however it varies also interculturally. In any known society, its members are not granted exactly the same portion of free time. As Nash argues, "In no society does everyone have the same amount of leisure time, and in some, say, a typical agriculturally-based state, the differences between different social strata may be great" (Nash 1996, 63). This approach is subject to criticism as it only deals with the issue of how tourists are produced, and does not pay attention to the secondary impacts: those on its actors, and those on the environment. This reality is emphasized in the next theory.

\section{Tourism as a form of acculturation}

Tourism became a social fact of a big importance, and as such influences individuals and whole communities of both hosts and guests. Not only do the hosts determine the changed perception of guests, but vice versa as the guests play a part in 


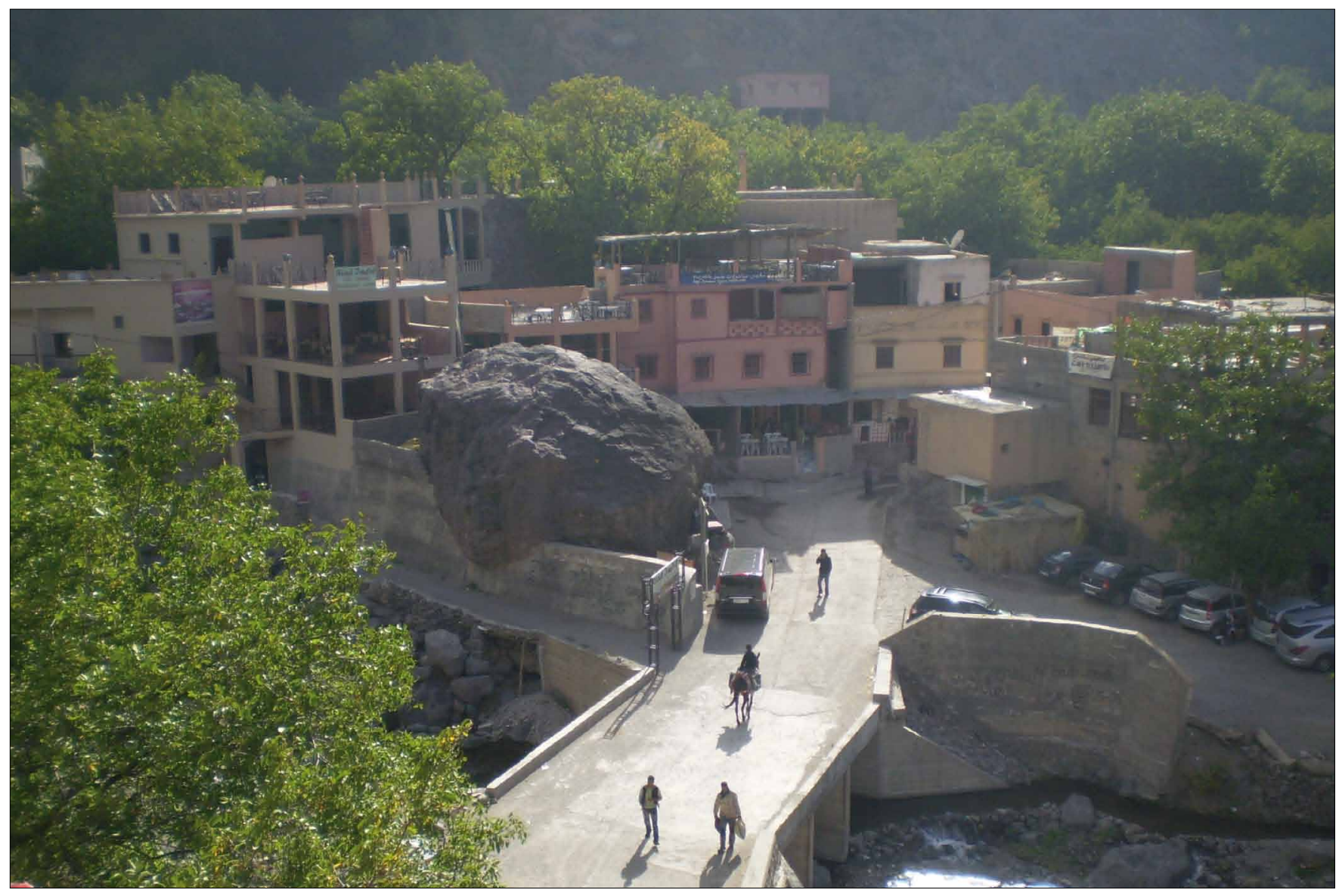

Fig. 2. View to the Imlil village.

changing the host community's culture. Another way to treat tourism is actually at hand; the next approach engages acculturation as a standpoint.

Travelling as a process working both directions has an impact on host population and contributes to a permanent modification of values and attitudes. Acculturation takes into consideration socialization when cultural elements are interiorized, and adaptive strategies that serve to get accustomed to new cultural features. It can also encompass revitalization and conflict functioning as a basis for structural order. Acculturation consists of contact situations, consequent social relations and finally of changes in the interacting cultures as a whole.

Sociocultural systems interplay between a change and an enduring order, yet one prevails the other. Anthropologists began to be aware of tourism when they realized it implied further development and change. These changes depend on the type of tourism; in the few past decades the differentiation in the tourism industry produced various categories, which are significant in a number of respects. Ecotourism derives from principles of sustainability, community-based tourism aims at avoiding the often harmful policies of conventional practices and heritage, and cultural tourism brings attention to the heritage values and historical circumstances of marginalized people (Chambers 2010, preface). Moreo- ver, new subfields of tourism are emerging and these days we can talk about "dark" tourism, medical tourism or birth tourism.

\section{Tourism as a mode of postcolonial behaviour}

Finally, tourism can be viewed as a form of postcolonial dominance over territories, which are less developed. It works as a tool that brings back to life representations of the past and idealized colonial images. However, the recent situation has slowly proved this distinction should be revised as the countries of Global South are slowly becoming producers of tourists not only the recipients.

When it comes to tourism studies, they often put aside a diachronic perspective. Partly due to the relatively new subject of study, sufficient time has not passed to possess a detailed account of case studies containing data over a past few decades. A long-term study carried out by Helena Norberg Hodge, whose interest in the Ladakhi community dates back to the seventies of the twentieth century makes an exception. The province of Ladakh lies in the trans-Himalayan region of Kashmir. It consists of two districts, Buddhist and Muslim. Helena Norberg - Hodge first visited this place when it was still quite isolated from the influence of the Western culture. She met a culture which she later described as ope- 


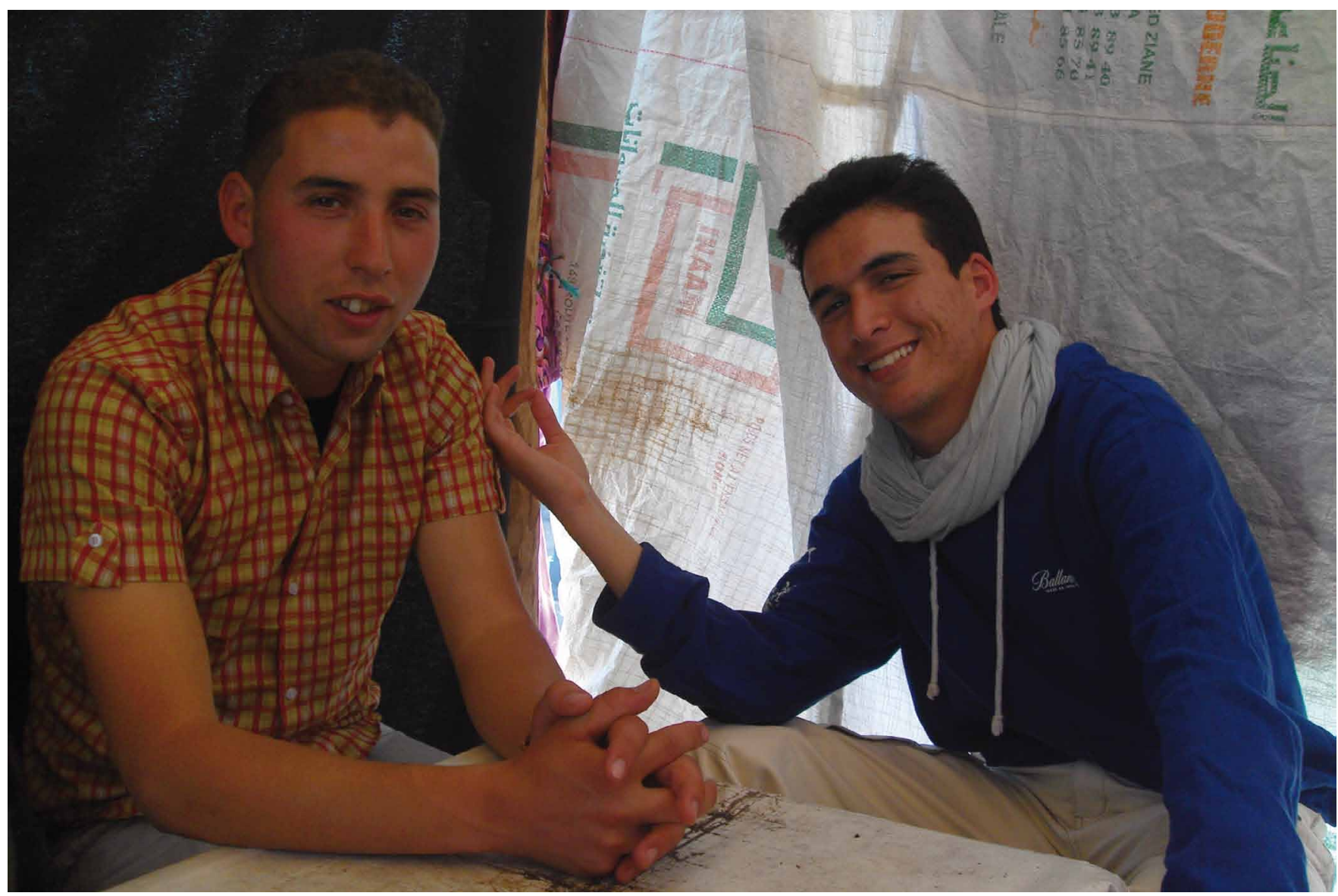

Fig. 3. Local tour guide Jamal with a friend.

rating on different basis from the Western industrial society, with its unique system of values, social and material structures. The monoculture, how she calls it, as the time passed started prevailing the original setting. "Today's conquistadors are development, advertising, the media and tourism" she adds (Norberg-Hodge 1991, 3). The traditionally inaccessible region marked with harsh climate and scarcity of resources had been protected from the influence of Western culture until tourists discovered its stunning beauty and started visiting the region. The advent of tourism has been documented as well as its gradual installation. Ladakh has become a unique anthropological laboratory examining tourism and providing a great example of a society resting upon basis, which is distant from our own society. Norberg - Hodge emphasizes the psychological impact of modernization, which is evident at every individual. "The impact of tourism on the material culture has been wide-ranging and disturbing. Still more significant, however, has been its impact on people's minds" (Norberg - Hodge 1991, 93). As monetary economy gets deeper in the core structures of the Ladakhi's culture, the level of dependence on the western system is more and more evident. The local sustainable economy that has proved its functioning over centuries is being replaced by the Western modern elements leading to consumerism represented by tourism among others.

\section{MODERN DIALECTICS: HIKERS AND FARMERS}

Zygmunt Bauman points out that the most powerful stratification factor of our era is mobility. People and things do not circulate freely; the move requires conditio sine qua non - the existence of material infrastructure such asroads, airlines, and communication technologies. These paraphernalias create an indispensable component of touristic infrastructure, and lead to the further change of sociocultural systems in the territories.

Morocco is a state in Northern Africa. It is washed by the Atlantic Ocean in the West, and borders on Algeria in the East. The country is a constitutional monarchy with a population of about 35 million people. The number of incoming tourists to Morocco has risen from 1.5 million in the 1980s to 8 million people in 2008 (In: http://morocco.realtyna.com/morocco-tourism.html). Between 15 and 18 million of them are Berber speakers. Berbers are indigenous people of Africa, who nowadays occupy mostly the interior parts of the country, mountains or desert areas. It is an ethnic group, which has own language ${ }^{1}$, oral traditions that are passed down to future

1 Nowadays three dialects of Berber language are identified Tachelhit, Tamazight and Tarifit. 


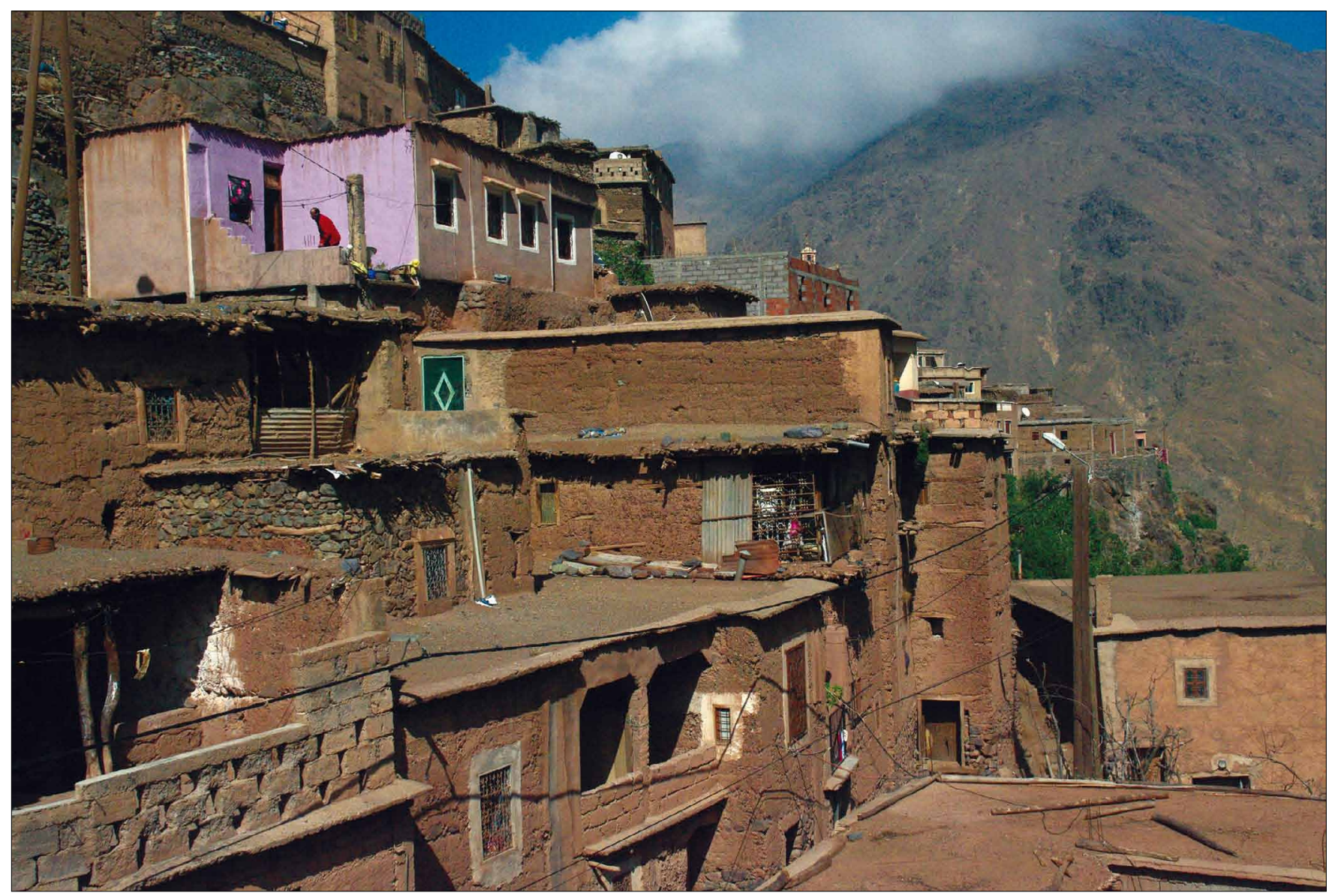

Fig. 4. Houses in the Imlil Valley.

generations, and a culture; that is manifested in the material products such as pottery, carpets or jewellery. At the foot of J'Bel Toubkal, the highest North African mountain, there is a valley encircled by sharp peaks casting their shadows on the green terraced fields and apple orchards. This corner of the mountains - Imlil Valley - is inhabited by a tribe of Ait Mizane people. They are farmers and herdsmen, who have been living within the borders of their own micro-world for centuries; and nowadays occupy a unique position in the regional context. They inhabit a valley, which lies on the gateway to the Toubkal Mountain, and as such receives a number of tourists coming to enjoy the reckless moments of mountain tourism. Whether the increasing number of visitors is a blessing or a disaster for the local population depends on the consideration of many factors and points of view, and we do not aim to pass this judgement.

The subsequent lines intend to explain the mechanism of acculturation, which contribute to the changing reality of people of Mizane as they experience it in a day-to-day life. Their story also reveals a history of colonial and postcolonial period in contemporary Morocco, which has been revived by mass tourism entering the area. The analysis deals with different kinds of narration, time distinction, market economy, modernisation and related phenomena, which are its necessary components.
The High Atlas Mountains split the country into two halves. Its peaks appear to touch the sky, and the slopes are scattered with tiny village settlements accompanied by dozens of stair-step irrigated fields with corn and vegetable crops that curl down the valley (fig. 1). Along with herding, such agriculture makes up the economic base of the Berbers and entails hundreds of tasks carried out in everyday routine. In the 1980 s the population counted some 2000 people. Nowadays, 30 years later, owing to accessible healthcare the number has augmented to some 7000 inhabitants. Modernisation in the region would appear no matter what, but we believe that the crucial element, which triggers it is a rising presence of people from the outside world.

The Ait Mizane used to live within the mountain micro-cosmos until the 1930s. In the mid-thirties, the colonial administrators in Marrakech signed a document, which entitled Travaux Publics agency to build up a road leading into the heart of the mountains (Miller 1984, 121). This little road meant a revolution, as the Ait Mizane and other tribes entered the map of Morocco. Suiga or a little suq (market place) where the road finished was later labelled as Garage, because all outsiders coming along the road had to leave their vehicles and continue walking (fig. 2). Garage remained the place where travellers emerged from the cabins of taxis into 
the sharp light of local climate. These days, the clash between the incoming tourists and waiting locals usually happens here. It is a border zone and by crossing it the tourists are becoming temporary actors at the Tourism Mundi of Imlil. The other group on incomers skips this part of the loop since all the details about accommodation and trekking are settled by the the tour operators.

Tourism in the area is nowadays articulated by two narrations. The first one tells a story of organized, packaged-like tours, which are coordinated by tour operators and owners of hotels, while the other is more organic and consists of individuals coming to the parking lot negotiating the accommodation opportunities and hiking options directly with the locals. Both these modes contribute to the transformation of the local community, but each of them is manifested in a different way. The first mentioned case, when the whole industry is in hands of outsiders, implies imperialistic or even neo-colonial scheme.

Jamal is a young male, who lives with his parents, sisters and brothers in a village of Ait Souka. They are fourteen children in total, some of them have already left, and formed own families, others still live in the parent's house (fig. 3). He speaks Tashelhit, Arabic, French and English, and cooperates with a UK registered company offering trekking tours and educational visits. A little plastic card with his photo and personal details certifies him as an official guide of the agency, which calls him everytime there is a group of tourists transferred from Marrakech to the Imlil valley. The money he receives for his job, which often means staying a few days and nights away from the home village, significantly contributes to the family budget. However, the amount reflects the financial reality in Morocco but it does not mirror the price each tourist participant spent on the trip. The massive profit therefore goes to the company owners, and it is not invested within the community.

The second frame of interaction is pinpointed by individual contacts of locals and individual tourists (often backpackers), and is based on more vaguely defined nature of contacts. Local men often get hired as guides or they even offer accommodation in their houses for some charge, which is comparable to everything in a Moroccan Muslim society, subject to negotiation.

Trekking guides, muleteers, workers in the hotels, restaurants and shops represent a segment of a society, which mingles with tourist directly. These people serve as mediators allowing the pieces of outside world to incorporate in the host culture, as the rest of the society does not have a first-hand contact with the social reality of the hotel lodges and cafes close to the parking lot.

The context of a local patriarchal culture implies a high degree of selectiveness in the participation in tourism processes. The barrier between female and male social world is evident; women are in charge of the households, and leave their home villages only accompanied by a male member of the family. Cultural traditions thus do not grant them the opportunity to participate in the tourism activities; further- more the ability of speaking a foreign language is missing in vast majority of cases. Tourism therefore favours men, who are multilingual, young and in particular cases strong enough to endure the demanding walking in a difficult terrain. On the other hand it excludes those, who do not have the required skills nor the potential to gain them.

Mountain guides, who often facilitate the communication between globals and locals, play a key role in the whole tourism process. Since the beginning of regional tourism, young villagers have been hired as guides or mountaineers. Tourism has therefore introduced a hallmark of wage labour that has led to slight individualisation within an originally rigidly patriarchal and hierarchical system. Consequently, the participation in the monetary economy is reserved for the families of the envolved male representatives and this situation has further repercussions in the community relationships as a whole:

1) First, it affected the gender relations in the host community. Not only are women in charge of the household as a whole during the absence of their husbands, but also with the rising appreciation of the money as a value, their share in the family life and service can be considered of lower importance.

2) Second, the arising issue of social stratification based on the access to the job opportunities linked with tourism is evident and should be a matter of profound investigation.

The influence of the monetary system on the traditional structures reconstructs time perception, which becomes discovered as a commodity open to use or waste. Men often leave their homes for days and this physical absence not only does require more responsibility from those who remained, but also helps create a gap between free and working time.

My Moroccan landlord makes his money by occasional guiding and even more occasional accommodation service. His family owns a few fields and an orchard of apple trees, which he takes care of with other members of his large family. Every morning after I got up, I would bring my breakfast up to the terrace to start my day. These morning meals were my small ritual where I made clear what tasks and when I wanted to accomplish that day. They also included an often short or sometimes long talk with the landlord. I always asked him about his plans for the day, and based on his answers, it soon became apparent to me, that for every day he had a main responsibility to do. This responsibility ranged from gardening, shopping in the city, repairing something around the house, helping relatives or catching tourists. Nevertheless, he was very flexible in performing the daily tasks as he was not subordinated to the higher social structure, which would imply penalties in case of not accomplishing them. On the other hand, I barely saw him during the day spending large intervals of doing nothing. No fixed schedule is applied to him and his peers. The deeper he will get engaged in the tourism industry and related social products it generates, he will come to realize and experience what consequences it brings. 


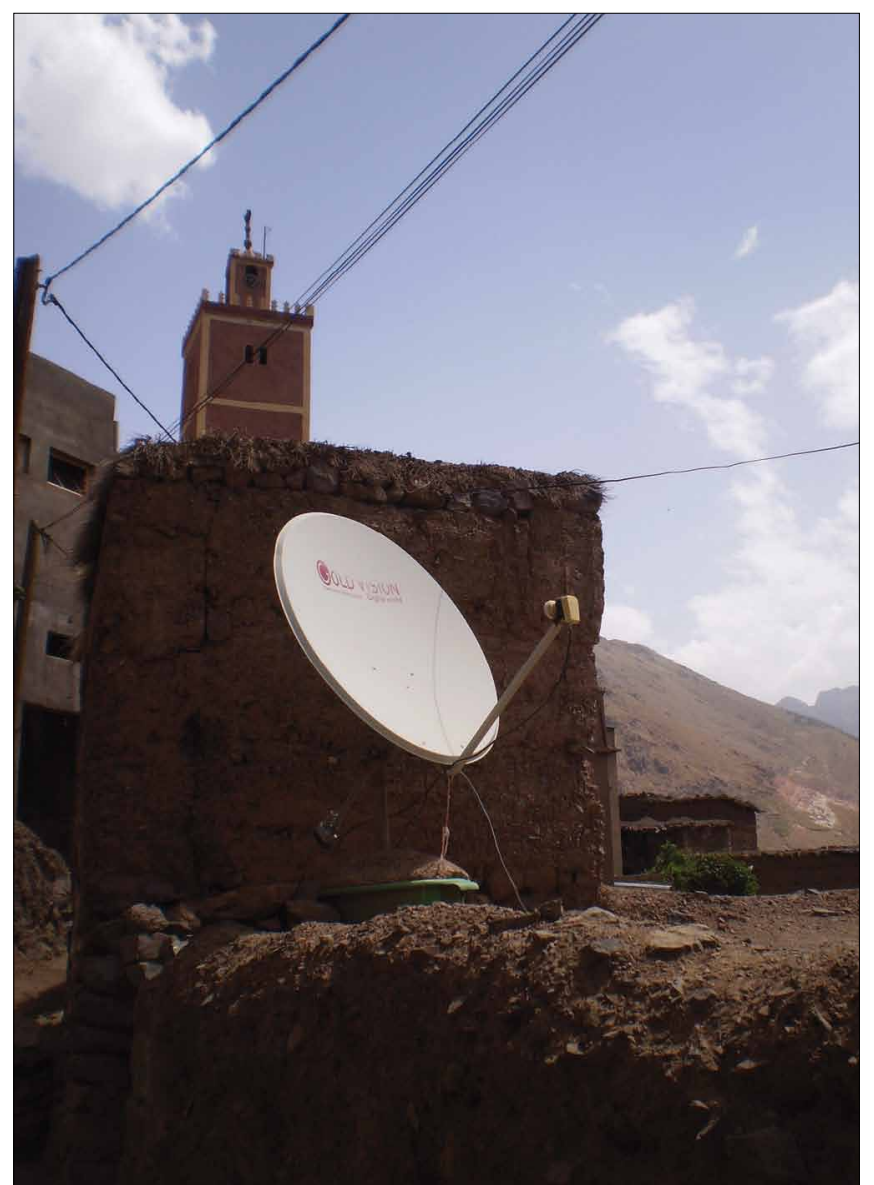

Fig. 5. Modes of acculturation.

The distinction between used and lost time is amplified by the migratory process for wage labour; jobs are always integrated into the wage labour frame with impersonal relations to the job market, implying it as a mere commodity.All in all, the whole paradigm has changed and the activities linked to tourism and wage labour; i.e. the prominent emergence of a monetary economy - seem to perturb the local reality. Many houses have invested acquired money into having running water in their homes. Not only are these local running water systems made of low-quality plastic piping that frequently leaks, but there is a social consequence to this change as well. People do not gather by wells to fetch water and gossip as they have done for centuries.

The Arabic soap operas are a very popular TV programmes especially among the young Berber women. The whole families gather around the high desk carrying a TV box decorated by artificial creeping flowers of psychedelic colours, and enjoy their daily portion of a glimpse into an urban society. The usually noisy households become less noisy to get after the final shot of the main hero back to its usual volume level of high voices of women. Every single house has a cap of a satellite plate on its flat roof, which is probably the most evident feature of the acculturation shift towards the western material culture. My visit to the Imlil valley in 2012 was my fourth encounter with the local people and their culture (fig. 4). During my second and third stay with the same family I happened to identify new pieces of machines, which were not there during my previous trip. The last time the family purchased a washing machine, and installed a water heater. I encountered in almost every house I have visited these little steps towards urban/western lifestyle. Houses are nowadays built of bricks instead of traditional clay and straws. Examples of material change are noticeable on every step, and create a counterpart to the changes of social aspects of the traditional society and its structure.

Berbers constitute a minority in their country. They have gone through centuries of neglect and oppression from the national authorities as well as colonial administrators. Only in the recent year their native languages started to be acknowledged, and taught at schools. Their sense of identity enhanced both by the spatial isolation and social separation made their culture a very coherent and strong system, which does not allow many aspects to enter and reshape the basis of the culture. Despite the changes counted in the previous lines, the aspect of spatial and also social isolation of the domestic and touristic sphere is very evident. The tourism has found its articulation and place in the context of the traditional society, but more than a replacement of certain phenomena, it shifted the previously existing schemes and incorporated in the existing context (fig. 5).

The postmodern world is characterized by vast transnational flows of people, capital, goods, and ideas (Appadurai 1991). We should still differentiate between the changes brought about by modernisation and tourism. The tourism flow is apparent only in the valley of Imlil. Other valleys distant only a few kilometres experience a completely different reality. Though new houses are also built from new modern materials, and roofs decorated with satellites, the intervention of western phenomena is less evident here. As I was once told in a little village only some 7 kilometres far away from the Imlil valley named Tagadirt Ait Ali, during a meal consisting of homemade hot roundy bread dipped in milk and sweet mint tea: "The people here don't even know what a tourist means. They grow their apples, and then sell it in Marrakech. That's it."

\section{TOURISM AND PAPUA NEW GUINEA}

The island of New Guinea maintains a reputation of one of the last places on the planet where it is possible to encounter the "witnesses of the Stone age". A great number of travellers incorrectly suppose that New Guinea is inhabited by tribes, which have not come in touch with any representant of the Western civilization at all. The reality is different though. The last groups of humans resisting the contact with civilization were spotted by patrols in the sixties of the twentieth century. Nevertheless, the reputation of New Guinea as a savage place continues to exist, and as such a place it attracts tourists. The 


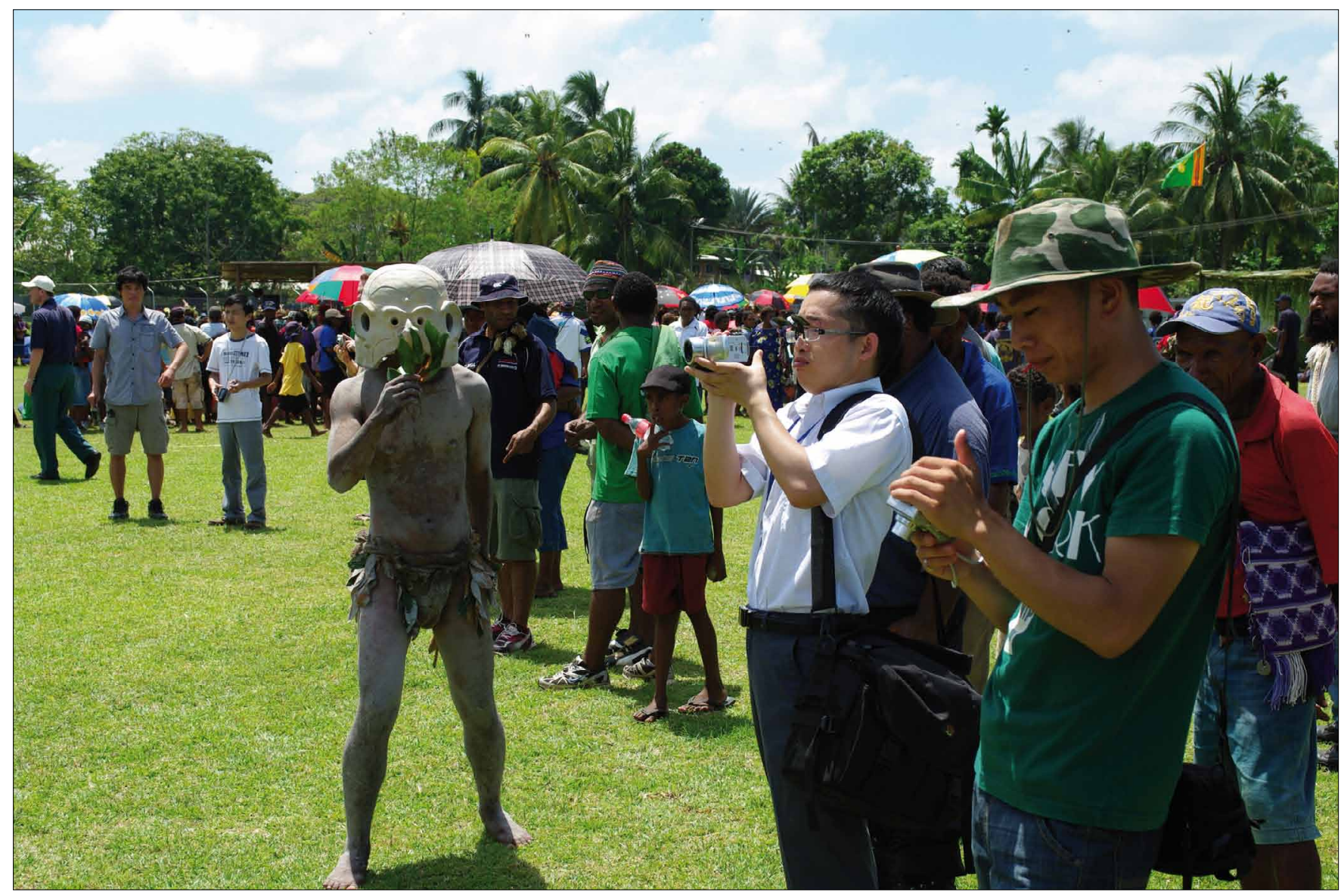

Fig. 6. Cultural show in Madang.

number of incoming people is augmenting year after year. We will turn our attention to the eastern part of the island - the politically autonomous state Papua New Guinea (PNG). A glance at the statistics reveals that in 2011 more than 164000 people travelled to PNG. For the local economy, this number represents a contribution of 1.6 billion $\mathrm{PGK}^{2} .21 \%$ visitors of the stated count came to spend their holidays (Visitor Arrivals Summary 2011, 2012).

It is possible to identify destinations, which tourists tend to give preference while considering the places to spend vacation. In Papua, the frequent aims of tourist trips are Mt. Wilhelm, the highest mountain of PNG, coral gardens near the town of Madang, Kokoda Track and cultural events in the Highlands and on the Sepik River. The following pages will be dedicated to travelling. People travelling in PNG are doing so for multiple reasons; they strive to enjoy some adventure, rest, experience the dark tourism and also different cultures. The range of tourist attractions is of course wider. The tourists can join The Crater Mountain Project aimed at the promotion of ecotourism (West 2006) or set off to Uruwa Valley to observe the endangered Tree Kangaroos (Hubeňáková \& Soukup, 2012). For many incoming people, the principal reason for visiting the locality is thus the abundant natural diversity,

2 The amount of almost 740 bil. USD which PNG offers. In 2011 45\% tourists stated the main motive for their choice of PNG to be the natural beauties (2011 Visitor Survey Report, 2012).

\section{Towards the Adventure}

Mount Wilhelm is the highest mountain in Papua New Guinea at 4,509 metres. Its peak is sometimes capped with snow, although it usually quickly melts. It is said to be the highest mountain in the Pacific since Puncak Jaya (5040 m), the highest Guinea peak is located in the Indonesian part of the island. The first successful ascent to Mt. Wilhelm is ascribed to an Australian patrol officer Leigh Grant Vial (1909-1943) who climbed it in 1938. Nowadays, the Vial's followers have a great deal of possibilities to sign in the climbing programs designed by the local inhabitants. The existing infrastructure and tailored excursions help minimize the risks of the ascent, and provide comfortable conditions within the realm of the local reality. Keglsugl village occupies a territory at the altitude of 2600 meters. The villagers are significantly oriented at the tourism sector. Numerous ges houses dotting the village, guides and fixed prices for their service serve as a proof of the establishment of the tourism sector. Price for the guide varies between 60 and 80 Kina per day ( 30 - 37 USD per day). The Track from Keglsugl to the top of Mt. Wilhelm takes two days 


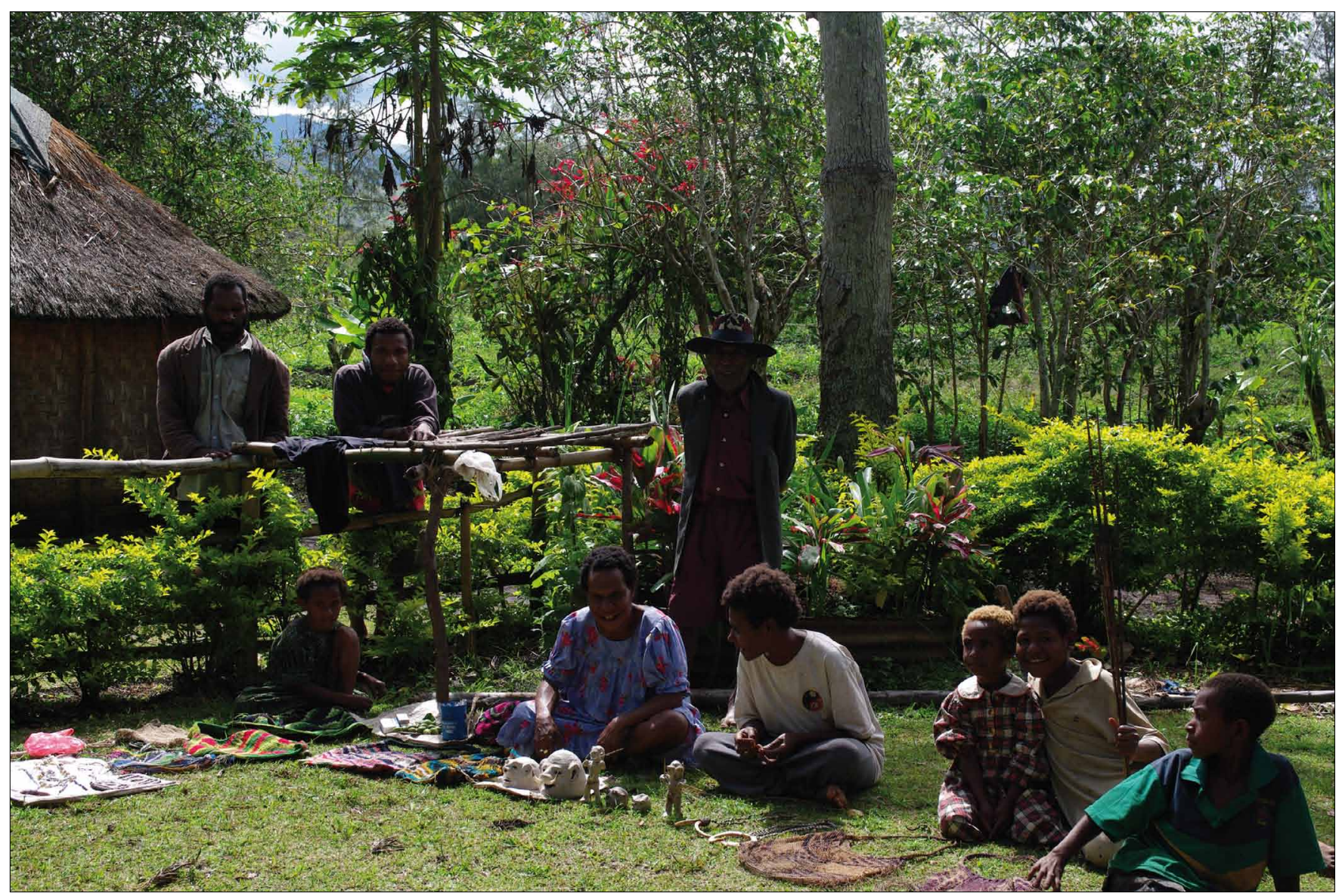

Fig. 7. Selling souvenirs in Komunive village.

and without being accompanied by a trekking guide, it can turn into a fairly dangerous enterprise. Statistics reveal that mountain climbing does not represent a leading activity carried out by tourists in the area. Only $13 \%$ stated it as the main reason of their trip to PNG (2011 Visitor Survey Report, 2012).

\section{Coral Gardens of Madang}

A traveler Michael Moran regards the port town Madang to be one of the most charming of the whole island. Others did not waver to proclaim it the prettiest town in the Pacific (Moran 2003). The former German colonial town Friedrich Wilhelmshafen (Madang these days) was destroyed by the Japanese troops during the World War II, therefore it had to be later restored. Hitherto, the reminders of fighting are one of the main tourist attractions in the town. Furthermore, Madang has gained an excellent reputation as a diving site. Lonely Planet travel guide describes it, "Excellent visibility, stunning tropical coral and fish life and countless WWII wrecks make the diving and snorkelling around Madang world famous"(McKinnon, Carillet, \& Starnes 2008, 142). There are a few luxury hotels offering services of premium quality including a range of facultative trips to the local sightseeings. The specialized dive centers provide dive trips to the renowned Barrier Reef,
Planet Rock or to the wrecks of the war machines sunk at the bottom of Astrolabe Bay. Scuba diving and snorkeling are noted as the main objective of the PNG visit by $45 \%$ tourists; Madang province ranks among the top Papua destinations (2011 Visitor Survey Report, 2012).

\section{Dark tourism in PNG}

The contemporary social science discourse reflects a cultural phenomenon, which came into existence under the label "dark tourism". The term was coined by John Lennon and Malcolm Foley. In the publication Dark Tourism (1996), the authors pointed out at the increasing interest in visiting places of human sufferings and pain - the itineraries of travel agencies offer trips to ossuaries, cemeteries or sites associated with tragedy. Sharpley defines dark tourism as, "Tourism to sites or attractions that are associated with death and disaster"(Sharpley 2006, 217). The first reflections of the phenomenon should be ascribed to an American writer and journalist Patrick Jake O'Rourke (born 1947), who is the author of a guidebook Holidays in Hell (1988). In the introduction, he confesses the motives for writing such a peculiar book. "I'm bored by ordinary travel. See the Beautiful Grand Canyon. Okay, I see it. Okay, it's beautiful. Now what?... Well, the planet I've got a chance 


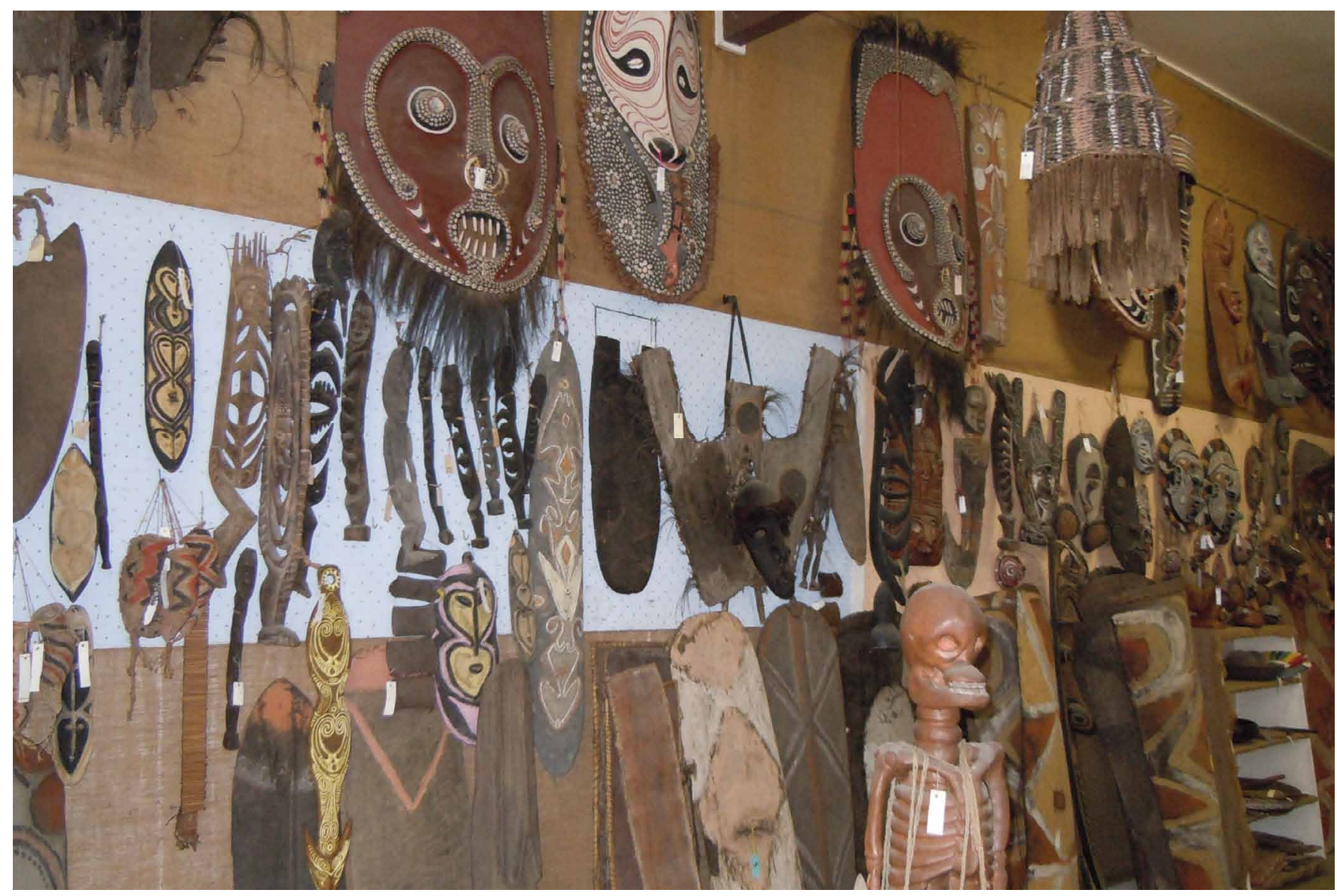

Fig. 8. It is the tradition that sells.

to visit is Earth, and Earth's principal features are chaos and war. I think I'd be a fool to spend years here and never have a look"(O'Rourke 1988, 22). To sum up, dark tourism is a recently constituted field of an academic interest. Nevertheless, it receives an increasing scholarly attention. One of the last attempts of providing an account of dark tourism can be considered an anthology edited by Richard Sharpley (born 1956) and Philip Stone The Darker Side of Travel (2009). They noticed an enormous rise of travelling to the dark sites in the last fifty years. The interest in travelling to places related to death, suffering and catastrophes is also reflected in the offers of travelling agencies. The authors mention an example of the World Trade Center in the United States, which was destroyed in the September 11 attacks. The number of tourists coming to see Ground Zero doubled since 2001. In 20023.5 million people visited the site (Sharpley \& Stone 2009).

Graham Dann identified five main categories of places and attractions of dark tourism: perilous places, houses of horror (houses where acts of violence took place), fields of fatality (e.g. a battlefield), tours of torment (trips to places of a mutilation or murder), themed thanatos (memorials commemorating death and suffering) (see Dann 1998).

A place which can be labeled as a dark tourism site in Papua New Guinea is a Kokoda Track. In 1942, it was a site of severe battles between the Japanese and Australian forces. Dramatic battles along the $96 \mathrm{~km}$ long track where outnumbered Australian forces resisted the Japanese affected the further military situation in the Pacific. After the Japanese lost the battle at Kokoda, they did not manage the military domination of Australia, therefore they did not secure the control over the strategic places in the Pacific region. Kokoda Track connects Owen's Corner close by Port Moresby with the Kokoda village on the other side of the Owen Stanley Range. More than 600 Australian soldiers did not survive the fierce battles in an extreme tropical terrain. More than one thousand soldiers were wounded (Reid 2007).

An endurance running race called Kokoda Challenge race commenced in 2005. The racers strive to reach the end of the difficult track as soon as possible. It leads across a difficult terrain of Southeastern New Guinea. Besides the annual race, it is also a famous track, which is walked by several thousands of tourists every year. Despite the considerable decline of visitors, Kokoda Track was visited by almost 3000 people in 2011 (Carlsen 2012). The trekkers have to climb and descend 5000 meters in total. The difference in altitude roughly corresponds to the ascent to Mont Blanc, the European highest mountain; however the conditions go beyond any comparison. Because of the frequent rainfall, the track is constantly heavily soaked, 
The environment is a perfect breeding ground for leeches and mosquitoes, which transmit malaria. Deaths are not exceptional. Organized treks usually last about nine days, and cost almost 4000 USD (Carlsen 2012). Kokoda Track belongs to the country's most popular tourist sites, and it features an important contribution to the PNG economy. Tracking as a main goal of the PNG visit was stated by $38 \%$ of tourists in 2011. More than $50 \%$ of the respondents came from Australia, and they noted as a reason for their visit the war sites and memorials (2011 Visitor Survey Report, 2012).

\section{It is the tradition that sells}

The desire to experience and enjoy the cultural diversity constitutes the main motive for 36\% of PNG visitors in 2011 (2011 Visitor Survey Report, 2012). PNG entered the general consciousness as a land of an immense language, cultural and natural diversity. Owing to the intensive contacts with Australian and European tradesmen in the course of the twentieth century, the local cultures either went through a dramatic transformation or even ceased to exist. Nevertheless, the country still promises to offer a glimpse of its famous past. The cultural shows represent one of the attractions which lure tourists. They are held chiefly to commemorate the Independence Day, the anniversary of PNG assumption of Independence in 1975. A cultural show in the province's capital in Eastern Highlands has gained a worldwide fame. During the show in Goroka, more than a hundred dance groups from Highlands perform their folklore dances. Similar cultural shows are held in other towns at various other occasions (fig. 6). Apart from the folklore presentations, tourists usually seek native artifacts and souvenirs, which are many times designed to satisfy the presumed customers' taste, and finally to meet the maximum luggage size limit allowed by airline companies (fig. 7). Artifacts can be purchased at the markets or in the specialized souvenir shops (fig. 8).

An Australian filmmaker Dennis O'Rourke observes in the film Cannibal Tours (1988) a group of European and American tourists on their way down the Sepik River. O'Rourke participated in famous films from New Guinea - First Contact (1983) by Connoly and Anderson, and Trobriand Cricket (1976). Cannibal Tours capture a kind of a role swapping; tourists paid to see the wild Sepic cultures, who used to be known as cannibals (Mead 1935; Tuzin \& Brown 1983). Europeans and Americans eagerly point their cameras to the native performances. Soon it becomes clear, that the cannibals in the film title are not meant to be the Sepik villagers, but ubiquitous tourists obsessed with taking pictures of everything which seems worthy and at least a bit interesting. They are buying artifacts, bargaining, trading. The villagers are selling an image of their culture, which the tourists created in their minds. Linneikin (2004) noted that the tradition sells: art for tourists, culture shows, T-shirts and souvenirs. Likely the other Pacific people, inhabitants of New Guinea react to images, which are the constructs of the travel guides and travel journals. These generate marketable images "of a country forgotten in time" and offer it to those who come there for holidays.

\section{RESUME}

The theoretic part of the study summarizes the contemporary state of anthropology of tourism with a special emphasis placed on the key concepts and its representatives. In this part we noted four main theoretic approaches to tourism:

- Tourism as a ritual of transition

- Tourism as a form of superstructure

- Tourism as a form of acculturation

- Tourism as a mode of postcolonial behaviour

The second part of the study comprises of an analysis of the tourism industry in two localities, Morocco and Papua New Guinea. They were subject to the field research carried out by the authors of the study. This chapter aims to describe the mountains' main tourist attractions, and also strategies the local populations developed to provide service to the incoming tourists. Following up on the theoretical approaches introduced in the first part, some differences were identified between the localities.

As for Papua New Guinea, the phenomenon of dark tourism is a significant feature of the local reality. Due to the dramatic events of the WW2, certain sites have turned into the frequently visited memorials of the war conflicts. The High Atlas Mountains and J'Bel Toubkal National Park in particular is a target of the mountain tourism, which entails mountaineering services provided by local young men working as trekking guides and muleteers. The cultural shows and related phenomena identified in Papua New Guinea have not yet become a part of the local tourist offer. Compared to the Saruwaged Range, the tourism industry in High Atlas is more determined by the environmental conditions, which shape the whole sector.

To sum up, in both places the locals strive to get engaged in the tourism industry by the means of developing and improving the tourism infrastructure to make it an appealing destination, which is worth visiting.

\section{REFERENCES}

Appadurai, Arjun (1991): Global ethnoscapes: Notes and Queries for a Transnational Anthropology. P. 191 - 210 in Recapturing Anthropology: Working in the Present, ed. Richard G. Fox Santa Fe: School of American Research Press.

Botton, Alain de (2010): The Art of Travel. London: Vintage.

Brown, P. \& Tuzin, D. (eds.) (1983): The Ethnography of Cannibalism. Washington : Society for Psychological Anthropology.

Brunner, Edward (2005): Culture on Tour. Ethnographies of Travel. Chicago: The University of Chicago Press.

Carlsen, J. (2012): The Economic Significance of the Trekking on the Kokoda Track, PNG in 2011 Report to the Kokoda Track Authority. Curtin Sustainable Tourism Centre: Curtin University, Perth.

Chambers, Erve (2010): Native Tours. The Anthropology of Travel and Tourism. USA: Waveland Press, Inc.

Curtin Sustainable Tourism Centre (2012): 2011. Report to the Kokoda Track Authority. Curtin Sustainable Tourism Centre: Curtin

Dann, G. M. S. (1998) The Dark Side of Tourism. Etudes et Rapports Centre International de Recherches et d'Etudes Touristiques, Aix-en-Provence, serie L, 14, 1-31. 
Hubeňáková, J. \& Soukup, M. (2012): Nungon People of Uruwa. Červený Kostelec: Pavel Mervart.

Lanfant, Marie-Francoise (1989): "International Tourism Resists the Crisis." In: Leisure and Life-Style: A Comparative Analysis of Free time, ed. A. Olszewska and K. Roberts. London: Sage.

Linnekin, J. (2004). Tradition Sells: Identity Merchandise in the Pacific Islands. in ed. V Lockwood. Globalization and Culture Change in the Pacific Islands. New Jersey: Prentice Hall.

McKinnon, R., Carillet, J., \& Starnes, D. (2008): Papua New Guinea. London: Lonely Planet.

Mead, M. (1935): Sex and Temperament in Three Primitive Societies. New York: William Morrow and Company.

Miller, Andrew (1984): Imlil. A Moroccan Mountain Community in Change. USA: Westview Press.

Moran, M. (2003): Beyond The Coral Sea. London: Harper Collins.

Nash, Dennison (1996): Anthropology of tourism. Oxford: Elsevier Science Ltd.

Norberg - Hodge, Helena (1991): Ancient Futures. Learning from Ladakh. USA: Sierra Club Books, 1991.

O’Rourke, P. (1988): Holidays in Hell. New York: Grove Press.

Papua New Guinea Tourism Promotion Authority (2012): 2011 Visitor Survey Report. Port Moresby: Papua New Guinea Tourism Promotion Authority

Papua New Guinea Tourism Promotion Authority (2012): Visitor Arrivals Summary 2011. Port Moresby: Papua New Guinea Tourism Promotion Authority.

Reid, R. (2007): Kokoda 1942. Canberra: Department of Veteran's Affairs.

Sharpley, R. (2006): Travel and Tourism. Thousand Oaks: Sage Publications.

Sharpley, R., \& Stone, P. (2009): The Darker Side of Travel: The Theory and Practice of Dark Tourism. Buffalo: Channel View Publications.

Smith, Valene (1977/1989): Hosts and Guests: The Anthropology of Tourism, 2nd ed. Philadelphia: University of Pennsylvania Press.

Turner, Victor (1977): The Ritual Process. Ithaca: Cornell University Press.

Wang, Ning (2000): Tourism and modernity. A sociological analysis. Oxford: Elsevier Science Ltd.

West, P. (2006): Conservation Is Our Government Now. Durham: Duke University Press.

\section{AUTHORS}

Konopíková, Michaela (born $17^{\text {th }}$ November 1984), Czech socio-cultural anthropologist. She is a $\mathrm{PhD}$. candidate at the Faculty of Arts, Charles University in Prague. Her dissertation thesis deals with anthropology of tourism, globalization and transnational processes in developing countries. In 2009, 2011, 2012 and 2014 she carried out a field research among the Berber tribes in the central part of High Atlas Mountains in Morocco.

Contact: Mgr. Michaela Konopíková, Institute of Ethnology, Charles University in Prague, Faculty of Arts; Celetná 20, Prague 1, 11000. E-mail: michaela.konopikova@gmail.com.

Soukup, Martin (born 26 $6^{\text {th }}$ March 1977) is a Czech cultural anthropologist. He is an associate professor at the Institute of Ethnology at Faculty of Arts, Charles University in Prague. He focuses on history, methodology and theory of anthropology and bio-culturology. Soukup is particularly interested in the culture of Melanesia. In 2009 he undertook an anthropological pre-research in Papua New Guinea in the three local communities - Wannang (Madang Province), Kegeslugel (Chimbu Province) and Yawan (Morobe Province). In 2011 he returned to Yawan. Besides numerous papers and articles, he is also an author of the textbook Essentials of Cultural Anthropology (2009; in Czech). He published monographs Bioculturology: Evolution and Culture (2010; in Czech), Culture: Bioculturological perspective (2011; in Czech), Anthropology and Melanesia (2013; in Czech), Fieldwork in Social and Cultural Anthropology (2014; in Czech) and co-authored Nungon People of Uruwa (2012) and The Body (2014; in Czech).

Contact: Doc. PhDr. Martin Soukup, Ph.D., Institute of Ethnology, Charles University in Prague, Faculty of Arts; Celetná 20, Prague 1, 110 00. E-mail: martin.soukup@ff.cuni.cz. 
